\title{
Features of education of patriotism in children of primary school age by means of folklore
}

\author{
A.S. Ryleeva ${ }^{1 *}$, E.V. Yemanova ${ }^{2}$, and E.A. Khomutnikova ${ }^{3}$ \\ ${ }^{1}$ Federal State Budgetary Educational Institution of Higher Education "Kurgan State University", \\ Kurgan, Russia \\ ${ }^{2}$ Federal State Budgetary Educational Institution of Higher Education "Kurgan State University", \\ Kurgan, Russia \\ ${ }^{3}$ Federal State Budgetary Educational Institution of Higher Education "Kurgan State University", \\ Kurgan, Russia
}

\begin{abstract}
The article deals with the problem of education of patriotic qualities in children of primary school age. Primary school age is a sensitive period for the development of spiritual and moral qualities of a person. To monitor the level of patriotism development, we studied motivational, intellectual, sensual, volitional criterias.. Based on the results obtained, we have developed a program of work with primary school age children on the patriotic education. To develop attitudes towards patriotic values, we used the means of folklore, which have ample opportunities to familiarize children with their culture origins. The developed program "Russia is our home!" is aimed at instilling in children love and respect for their native land, familiarizing students with the study of the heroic history of the Fatherland, local history, search and research activities, national traditions, culture study and promotion.
\end{abstract}

\section{A problem statement}

In the Law "On Education" [1], the Federal State Educational Standard (approved by order of the Ministry of Education and Science of the Russian Federation dated 06.10.2009 No. 373) and the Concept of Spiritual Development and upbringing of the personality of the citizen of Russia special attention is paid to education and upbringing of a person with the traits of a citizen - a patriot of Motherland one who is able to successfully realize civil obligations in a peaceful and wartime [2].

Modern opportunities to overcome negative tendencies associated with the modern society patriotic values loss are being demonstrates the Resolution of the Government of the Russian Federation dated December 30, 2015 No. 1493 "On the State Program "Patriotic Education of Citizens of the Russian Federation" for 2016-2020 [3]. This program defines the basic lines of formation of the concept of patriotic education citizens of the Russian Federation, includes the patriotic upbringing basics and directions.

\footnotetext{
* Corresponding author: prof-ped.gpa@mail.ru
} 


\subsection{The objective of the work}

Primary school age is the most sensitive period for upbringing positive personality traits, including patriotism. Flexibility, the well-known suggestibility of children, their trustfulness, tendency to imitation and the teacher enormous authority, create favorable preconditions for a successful solution of this problem. Many psychologists L.I. Bozovic, L.S. Vygotsky, D.B. Feldstein $[4,5,6]$ believe that it is precisely in the primary school age that an active the process of accumulating knowledge about positive and negative in life and society, about relationships between people, about the freedom to choose one way or another of behavior takes place.

The problem of patriotic education of primary school children was studied by N.S. Krupskaya, A.S. Makarenko, V.A. Sukhomlinsky, L.V. Kokuev [7, 8, 9, 10] and others. A holistic pedagogical understanding of this problem leads to the need to search for effective ways of orienting the school towards the humanistic and practical essence of education. Prediction of the process of moral education primary school children is carried out on the basis of personal, procedural, integrative-differentiated approaches. A personal approach allows to focus on the inclinations and abilities, on the level of development of children, their armament with knowledge, skills and abilities, the degree of a civil-patriotic orientation formation, i.e. the nature of interests, needs, settings, perception of the world [12].

This gave us a reason to build our own theoretical and practical research in such a way that, based on the theoretical material, we can present new practical data that can complement the pedagogical base. The theoretical basis of the research is the work of such domestic and foreign authors as G.S. Altshuller, B.P. Baydenko, V.P. Bespalko, I.P. Volkov, A.A. Getmanskaya, T.E. Zlygosteva, V.A. Kavera, M.V. Klarin, V. Knyaginin, N. Trunova, I.A. Kolesnikov, A.N. Dukkardt, D.S. Saenko, E.A. Sleptsova, K.V. Kanzychakov, S.D. Karakozov, A.Yu. Uvarov, N.Sh. Kozlov, N.S. Kramarenko, A.Yu. Kvashin, M.V. Mazay, I.Ya. Lerner, T.M. Mikhailenko, M.Yu. Oleshkov, B.A. Sazonov, G.K. Selevko, T.B. Feiling, A.S. Chernov, M.A. Choshanov, V.D. Shadrikov, I.S. Yakimanskaya and others.

\section{Results of the research}

To determine the level of patriotic upbringing of primary school age children, an experement was conducted at the FGKOU "Secondary School No. 3" city of Priozersk, Karaganda region, in which 11 children from the $4^{\text {th }}$ grade took part. Experiment time: September 2020.

At the ascertaining stage, the primary school children patriotic education level diagnostics was carried out.

To implement this stage, a selection of methods for diagnosing the primary school children patriotic upbringing level was carried out.

Based on the developed by T.M. Maslova criterias: motivational, intellectual, sensual, volitional, we have carried out 3 methods to identify the patriotic feelings level. The results were analyzed and the average score for the patriotic feelings level development was determined. Let's consider each method and the obtained results on it in more details.

Method 1. "I am a Fatherland patriot".

Purpose: to determine the children's level of manifestation interest in their city, its historical past, the frequency of the expressed desires of them for patriotic activity (Table 1). 
Table 1. The results of the method "I am a Fatherland patriot".

\begin{tabular}{|c|c|c|c|c|c|c|c|c|c|c|c|c|c|c|c|c|c|c|c|c|c|c|c|c|}
\hline \multirow{2}{*}{$\begin{array}{c}\text { Surname, } \\
\text { Name }\end{array}$} & \multicolumn{22}{|c|}{ Question number, results in points } & \multirow[b]{2}{*}{ 窇 } & \multirow[b]{2}{*}{ 离 } \\
\hline & - & $N$ & $m$ & $\nabla$ & $n$ & 0 & $r$ & $\infty$ & $a$ & 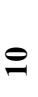 & $=$ & 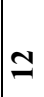 & 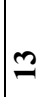 & \pm & & $\theta$ & $\stackrel{0}{-1}$ & 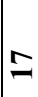 & $\underline{-\alpha}$ & e & 2 & 귀 & & \\
\hline G. Suzanne & 2 & 0 & 1 & 2 & 0 & 2 & 1 & 2 & 2 & 1 & 2 & 2 & 1 & 1 & & 0 & 1 & 2 & & 2 & 2 & 1 & $\mid$\begin{tabular}{c|}
$27 \mathrm{pt}$ \\
$67.5 \%$
\end{tabular} & A \\
\hline L. Nikita & 2 & 0 & 0 & 2 & 1 & 2 & 1 & 2 & 1 & 2 & 2 & 2 & 1 & 1 & & 0 & 2 & 1 & & 2 & 1 & 2 & \begin{tabular}{|c|}
$27 \mathrm{pt}$ \\
$67.5 \%$
\end{tabular} & A \\
\hline L. Yuri & 1 & 0 & 0 & 2 & 1 & 2 & 1 & 1 & 2 & 2 & 1 & 2 & 0 & 2 & & 0 & 2 & 1 & & 1 & 1 & 1 & $\left|\begin{array}{c}23 \mathrm{pt} \\
57.5 \%\end{array}\right|$ & A \\
\hline N. Ivan & 1 & 0 & 1 & 0 & 0 & 2 & 1 & 2 & 1 & 2 & 1 & 2 & 1 & 2 & & 0 & 1 & 2 & & 1 & 1 & 2 & $\begin{array}{c}23 \mathrm{pt} \\
57.5 \%\end{array}$ & A \\
\hline N. Lera & 1 & 0 & 0 & 0 & 0 & 1 & 1 & 1 & 1 & 0 & 0 & 0 & 0 & 0 & & 0 & 1 & 0 & & 5 & 1 & 0 & \begin{tabular}{c|}
$7 \mathrm{pt}$ \\
17.5 \\
$\%$
\end{tabular} & $\mathrm{~L}$ \\
\hline N. Andrei & 2 & 1 & 1 & 2 & 0 & 2 & 1 & 1 & 2 & 2 & 2 & 2 & 2 & 1 & & 1 & 2 & 1 & & 2 & 1 & 2 & $\begin{array}{l}30 \mathrm{pt} \\
35 \%\end{array}$ & L A \\
\hline N. Natalia & 2 & 1 & 1 & 2 & 1 & 2 & 1 & 2 & 2 & 1 & 2 & 2 & 1 & 2 & & 0 & 1 & 2 & & 2 & 2 & 1 & $\begin{array}{l}30 \mathrm{pt} \\
75 \%\end{array}$ & A \\
\hline P. Daria & 2 & 1 & 1 & 2 & 0 & 2 & 1 & 1 & 2 & 2 & 2 & 2 & 2 & 1 & & 1 & 2 & 2 & & ? & 1 & 2 & $\left|\begin{array}{c}19 \mathrm{pt} \\
47.5 \%\end{array}\right|$ & L A \\
\hline S. Danil & 1 & 1 & 0 & 0 & 1 & 1 & 1 & 0 & 0 & 2 & 1 & 2 & 1 & 2 & & 1 & 1 & 2 & & 2 & 0 & 1 & $\left|\begin{array}{c}21 \mathrm{pt} \\
52.2 \%\end{array}\right|$ & L A \\
\hline T. Sergei & 2 & 1 & 1 & 2 & 2 & 2 & 1 & 2 & 2 & 1 & 2 & 1 & 1 & 2 & & 0 & 1 & 2 & & 2 & 2 & 1 & \begin{tabular}{|l|}
$30 \mathrm{pt}$ \\
$75 \%$
\end{tabular} & A \\
\hline F. Evelina & 1 & 1 & 1 & 0 & 0 & 0 & 0 & 1 & 1 & 1 & 1 & 0 & 0 & 0 & & 0 & 0 & 1 & & & 1 & 0 & \begin{tabular}{|c|}
$9 \mathrm{pt}$ \\
$22.5 \%$
\end{tabular} & $\mathrm{~L}$ \\
\hline
\end{tabular}

The group scored 246 points out of 440 possible. Average percentage - 56\%. The following results were identified in the group: 6 children have an average level of patriotic feeling development; 3 children - below average, and 2 children - low level.

2 Method "Complete the sentence".

Purpose: to determine the amount of knowledge of primary school children on the history of their hometown (Table 2). 
Table 2. Results of the "Complete the sentence" method.

\begin{tabular}{|c|c|c|c|c|c|c|c|c|c|c|c|c|c|c|c|c|c|c|c|c|}
\hline \multirow{2}{*}{$\begin{array}{c}\text { Surname, } \\
\text { Name }\end{array}$} & \multicolumn{18}{|c|}{ Question number, results in points } & \multirow[b]{2}{*}{ 苞 } & \multirow[b]{2}{*}{ 离 } \\
\hline & - & $N$ & m & t & in & 6 & $r$ & $\infty$ & $a$ & $\varrho$ & $\equiv$ & $\mathcal{Z}$ & $\cong$ & \pm & & $\Omega$ & 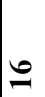 & $\Xi$ & & \\
\hline G. Suzanne & 1 & 0 & 1 & 1 & 0 & 1 & 1 & 0 & 1 & 0 & 1 & 1 & 1 & 1 & & 1 & 0 & 1 & $\begin{array}{l}12 \mathrm{pt} \\
70 \%\end{array}$ & $\mathrm{~A}$ \\
\hline L. Nikita & 0 & 1 & 0 & 1 & 1 & 0 & 1 & 0 & 1 & 1 & 0 & 0 & 1 & 1 & & 0 & 1 & 1 & $\begin{array}{l}10 \mathrm{pt} \\
59 \%\end{array}$ & A \\
\hline L. Yuri & 1 & 1 & 1 & 1 & 0 & 1 & 1 & 0 & 1 & 0 & 1 & 1 & 1 & & & 1 & 0 & 1 & $\begin{array}{l}13 \mathrm{pt} \\
76 \%\end{array}$ & $\mathrm{~A}$ \\
\hline N. Ivan & 1 & 0 & 1 & 1 & 0 & 1 & 1 & 0 & 1 & 0 & 1 & 1 & 1 & & & 1 & 0 & 0 & $\begin{array}{l}11 \mathrm{pt} \\
65 \%\end{array}$ & A \\
\hline N. Lera & 1 & 0 & 0 & 0 & 1 & 0 & 1 & 0 & 0 & 0 & 0 & 1 & 1 & ( & & 0 & 0 & 0 & $\begin{array}{l}5 \mathrm{pt} \\
29 \%\end{array}$ & $\mathrm{~L}$ \\
\hline N. Andrei & 1 & 1 & 0 & 0 & 1 & 0 & 0 & 0 & 1 & 1 & 0 & 1 & 0 & 1 & & 0 & 0 & 1 & $\begin{array}{l}8 \mathrm{pt} \\
47 \%\end{array}$ & L A \\
\hline N. Natalia & 0 & 1 & 0 & 1 & 1 & 0 & 1 & 0 & 0 & 1 & 0 & 0 & 1 & 1 & & 1 & 1 & 1 & $\begin{array}{l}10 \mathrm{pt} \\
59 \%\end{array}$ & A \\
\hline P. Daria & 1 & 1 & 0 & 0 & 1 & 0 & 0 & 1 & 1 & 1 & 0 & 1 & 0 & 1 & & 0 & 0 & 0 & $\begin{array}{l}8 \mathrm{pt} \\
47 \%\end{array}$ & L A \\
\hline S. Danil & 1 & 1 & 0 & 1 & 0 & 0 & 0 & 0 & 1 & 1 & 0 & 1 & 0 & 1 & & 0 & 0 & 1 & $\begin{array}{l}8 \mathrm{pt} \\
47 \%\end{array}$ & $\mathrm{LA}$ \\
\hline T. Sergei & 1 & 0 & 1 & 1 & 0 & 1 & 1 & 0 & 1 & 0 & 1 & 1 & 0 & & & 1 & 0 & 1 & $\begin{array}{l}11 \mathrm{pt} \\
65 \%\end{array}$ & $\mathrm{~A}$ \\
\hline F. Evelina & 1 & 0 & 0 & 0 & 1 & 0 & 1 & 0 & 0 & 0 & 0 & 1 & 1 & 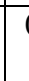 & & 0 & 1 & 0 & $\begin{array}{l}6 \mathrm{pt} \\
35 \%\end{array}$ & $\mathrm{~L}$ \\
\hline
\end{tabular}

The group scored 102 points out of 187 possible. The average percentage is $55 \%$.

The following results were identified in the group: 6 children have an average score; 3 children - below average score, and 2 children - low score.

3 Method "My attitude to my small homeland"

Purpose: to reveal the manifestation of primary school children patriotic emotions and feelings in relation to the "small homeland" (Table 3). 
Table 3. Results of the method "My attitude to my small homeland".

\begin{tabular}{|c|c|c|c|c|c|c|c|c|c|c|c|c|}
\hline \multirow{2}{*}{$\begin{array}{c}\text { Surname, } \\
\text { Name }\end{array}$} & \multicolumn{10}{|c|}{ Question number, results in points } & \multirow{2}{*}{ Total } & \multirow{2}{*}{ Level } \\
\hline & 1 & 2 & 3 & 4 & 5 & 6 & 7 & 8 & 9 & 10 & & \\
\hline G. Suzanne & 2 & 1 & 2 & 2 & 1 & 1 & 1 & 2 & 1 & 1 & $\begin{array}{l}14 \mathrm{pt} \\
70 \%\end{array}$ & A \\
\hline L. Nikita & 2 & 1 & 1 & 1 & 2 & 1 & 1 & 1 & 0 & 0 & $\begin{array}{l}10 \mathrm{pt} \\
50 \% \\
\end{array}$ & A \\
\hline L. Yuri & 2 & 1 & 2 & 2 & 1 & 1 & 1 & 2 & 0 & 1 & $\begin{array}{l}13 \mathrm{pt} \\
65 \%\end{array}$ & A \\
\hline N. Ivan & 2 & 1 & 2 & 1 & 1 & 2 & 1 & 1 & 1 & 0 & $\begin{array}{l}12 \mathrm{pt} \\
60 \% \\
\end{array}$ & A \\
\hline N. Lera & 1 & 1 & 1 & 0 & 0 & 1 & 0 & 1 & 0 & 1 & $\begin{array}{r}6 \mathrm{pt} \\
30 \% \\
\end{array}$ & $\mathrm{~L}$ \\
\hline N. Andrei & 1 & 1 & 2 & 1 & 0 & 1 & 1 & 0 & 0 & 1 & $\begin{array}{l}8 \mathrm{pt} \\
40 \% \\
\end{array}$ & $\mathrm{LA}$ \\
\hline N. Natalia & 2 & 1 & 2 & 1 & 2 & 0 & 1 & 0 & 1 & 1 & $\begin{array}{l}11 \mathrm{pt} \\
55 \%\end{array}$ & $\mathrm{~A}$ \\
\hline P. Daria & 1 & 1 & 2 & 1 & 0 & 1 & 1 & 1 & 1 & 1 & $\begin{array}{l}10 \mathrm{pt} \\
50 \%\end{array}$ & $\mathrm{~L} \mathrm{~A}$ \\
\hline S. Danil & 2 & 1 & 2 & 1 & 0 & 1 & 1 & 0 & 0 & 1 & $\begin{array}{l}9 \mathrm{pt} \\
45 \% \\
\end{array}$ & $\mathrm{LA}$ \\
\hline T. Sergei & 2 & 1 & 1 & 1 & 2 & 0 & 1 & 1 & 1 & 1 & $\begin{array}{l}11 \mathrm{pt} \\
55 \%\end{array}$ & A \\
\hline F. Evelina & 1 & 0 & 1 & 1 & 0 & 1 & 0 & 0 & 1 & 1 & $\begin{array}{l}6 \mathrm{pt} \\
30 \%\end{array}$ & $\mathrm{~L}$ \\
\hline
\end{tabular}

The group scored 110 points out of 220 possible. Average percentage - 50\%.

The following results were identified in the group: 6 children have an average level of patriotic feeling development; 3 children - below average, and 2 children - low level. Thus, comparing the obtained results of all three methods carried out with children of primary school age, we can conclude: the group scored 458 points out of a possible 847 , that is, the average percentage of patriotic upbringing among these students is $54 \%$, below average when compared with the assessment criteria. For the convenience of the methods results comparing, a diagram of the group results was compiled (Figure 1).

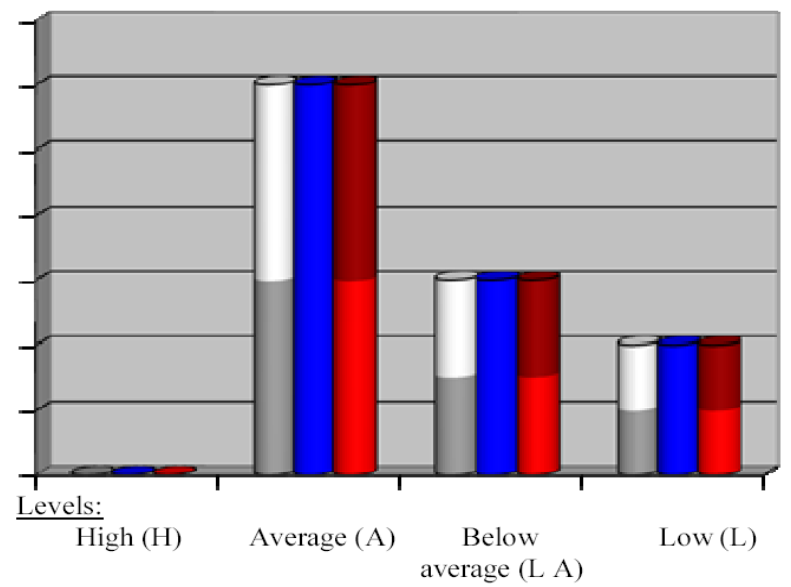

Fig. 1. Group summary table of diagnostic results. 
In general, according to the results of the three diagnostic techniques perfomance, 55\% of the this group of children have an average level of the patriotic education formation, low level - $18 \%$, high level - $0 \%$.

Based on realized by us the patriotic education level study results we made a decision on the need to create the association "Russia is our home!" on patriotic education of primary school age children by means of folklore and made a work program of the association.

The program is needed in order to help a primary school child to overcome difficulties with behavior and relationships, as well as to increase the level of knowledge about their country, native land, region. The program is aimed primarily at:

1. Raising children's love and respect for their native land.

2. The rise of the spiritual and moral culture of the younger generation.

3. Creation of conditions for the children's creativity, their civil formation and the development of an active life position.

4. Involvement of children in the study of the Fatherland heroic history, local history, search and research activities.

5. Study and promotion of national traditions, culture.

6. Patriotic education quality improving at school.

Let's consider the developed program in more detail.

Purpose: to awaken children's keen interest in the study of Russian folklore.

Tasks:

- educational: to give a general idea of the content and volume of the concept of "folklore", its classification, main genres, their functions, genesis and artistic originality.

- developing: develop outlook, interest in the folk word, its history.

- educational: bring up a sense of national pride for your people, its cultural heritage, form an attentive attitude to the word, culture of speech.

The focus of the additional educational program: patriotic. The program is a logically structured system aimed, on the one hand, at mastering knowledge, and on the other hand, at child's patriotism upbringing.

The inclusion of children in the creative process in the classes occurs gradually. This is facilitated by the teacher's attention to each child, maintaining a creative mood in the team. Familiarization of children with unknown material, reproduction of it, repetition, consolidation, search for new options - all this happens in game forms that arouse children's interest, and therefore increase the effectiveness of assimilation.

Classes involve the development of a variety of folklore works, genres, trends. Acquaintance with folk art expands the child's understanding of folk culture and traditions.

Age of children: this association can be attended by school children of $4^{\text {th }}$ grade.

The term for the implementation of this program is designed for 1 year of classes with children of primary school age. The teacher determines the preparation of newly admitted children with the help of diagnostics. According to the results of this diagnostics, children who have shown low results of knowledge on the research problem are selected for classes.

The number of classes and teaching hours per week is 64 hours (2 times a week) (Table 4). 
Table 4. Thematic planning of the association "Russia is our home!".

\begin{tabular}{|c|c|c|}
\hline № & Lesson topic & Forms and methods of teaching \\
\hline 1 & Introductory lesson: "Summer, oh, summer". & Lesson - game \\
\hline 2 & Folk games library: "Drake drove the duck". & Lesson - game \\
\hline 3 & Small folklore genres. & Verbal method \\
\hline 4 & Folk games library. & Lesson - game \\
\hline 5 & Small genres of folklore. Tongue-twisters. & Verbal method \\
\hline 6 & Folk holidays. & Story \\
\hline 7 & Master class: "Dolls amulets". & Individual \\
\hline 8 & Folk holidays. Autumn. & Lesson - game \\
\hline 9 & Folk games library: "Apple tree". & Lesson - game \\
\hline 10 & Performing at a concert, dedicated to Teacher's Day. & Demonstration \\
\hline 11 & Intonation skills. & Practical lessons \\
\hline 12 & Folk holidays. Pokrov. & Lesson - game \\
\hline 13 & The samovar has Slavic tea traditions. & Verbal method \\
\hline 14 & The samovar has Slavic tea traditions. & Lesson - game \\
\hline 15 & How people lived in the old days. & Story \\
\hline 16 & Folk games library. "Yasha". & Lesson - game \\
\hline 17 & Images of epic heroes. Epics. & Verbal method \\
\hline 18 & Intonation skills. & Practical lessons \\
\hline 19 & $\begin{array}{l}\text { The culture of Russian life (home interior, dishes, } \\
\text { utensils). }\end{array}$ & Cognitive method \\
\hline 20 & Role-playing games and etudes. & Lesson - game \\
\hline 21 & Russian costume. & Demonstration \\
\hline 22 & Role-playing games and etudes. & Lesson - game \\
\hline 23 & Folk holidays. Kuzminki. & Lesson - game \\
\hline 24 & Folk holidays. & Lesson - game \\
\hline 25 & What the Slavs believed in. & Verbal method \\
\hline 26 & Excursion to the local history museum. & Cognitive method \\
\hline 27 & Household folklore. Children's folk songs. & Practical lessons \\
\hline 28 & Amusing folklore. Word games. & Practical lessons \\
\hline 29 & Nicknames and teasers. & Verbal method \\
\hline 30 & Folk holidays. Winter solstice festival. & Lesson - game \\
\hline 31 & Folk holidays. Winter solstice. & Lesson - game \\
\hline 32 & Folk holidays. Christmastide. Generous. & Lesson - game \\
\hline 33 & Folk holidays. New Year. & Lesson - game \\
\hline 34 & Carols. & Story \\
\hline 35 & Folk holidays. Carols. & Lesson - game \\
\hline 36 & What's in your name. & Story \\
\hline 40 & Acquaintance with ritual songs. & Cognitive method \\
\hline 41 & Games-improvisations. & Lesson - game \\
\hline 42 & Games-improvisations. & Lesson - game \\
\hline $43-44$ & Round dance. & Verbal method \\
\hline $45-46$ & Round dance games. & Lesson - game \\
\hline $47-48$ & Round dance songs. & Lesson - game \\
\hline $49-50$ & Dances-flirting. & Lesson - game \\
\hline $51-52$ & Ah, pancakes, pancakes, pancakes ... & Practical lessons \\
\hline 53 & Calls. & Verbal method \\
\hline 54 & Master class "Spring". & Practical lessons \\
\hline $55-56$ & Folk games library. & Practical lessons \\
\hline $57-58$ & Role-playing games with sentences. & Lesson - game \\
\hline $59-61$ & Folk holidays. Easter. & Lesson - game \\
\hline $62-63$ & Folk holidays. Red hill. & Lesson - game \\
\hline 64 & Final lesson. & Generalization of the studied material \\
\hline
\end{tabular}


Expected result: increasing the level of knowledge of a patriotic orientation by means of folklore.

The developed program is aimed at improving the quality of patriotic education at school.

After the formative stage of the experimental work, we carried out a control stage in order to reveal the effectiveness of developed by us program of the association "Russia is our home!".

Method 1. "I am a Fatherland patriot".

The group has significantly improved its level and scored 253 points out of 280 possible. The average percentage is $76 \%$, i.e. the level of motivational and volitional criteria increased by $20 \%$ (Table 5 ).

Table 5. The results of the control stage of the methodology "I am a Fatherland patriot".

\begin{tabular}{|c|c|c|c|c|c|c|c|c|c|c|c|c|c|c|c|c|c|c|c|c|c|c|c|c|}
\hline \multirow{2}{*}{$\begin{array}{c}\text { Surname, } \\
\text { Name }\end{array}$} & \multicolumn{22}{|c|}{ Question number, results in points } & \multirow{2}{*}{ 苞 } & \multirow{2}{*}{ ] } \\
\hline & - & N & $m$ & + & n & 6 & r & $\infty$ & $a$ & 으 & $=$ & $\simeq$ & $\dddot{2}$ & 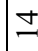 & & 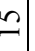 & $\because$ & $\beth$ & $\infty$ & 9 & & R & & \\
\hline G. Suzanne & 2 & 0 & 1 & 2 & 0 & 2 & 1 & 2 & 2 & 1 & 2 & 2 & 1 & 1 & & 0 & 1 & 2 & 2 & & & 1 & \begin{tabular}{|l|}
$34 \mathrm{pt}$ \\
$85 \%$
\end{tabular} & $\mathrm{H}$ \\
\hline L. Nikita & 2 & 0 & 0 & 2 & 1 & 2 & 1 & 2 & 1 & 2 & 2 & 2 & 1 & 1 & & 0 & 2 & 1 & 2 & & & 2 & \begin{tabular}{|l|}
$34 \mathrm{pt}$ \\
$85 \%$
\end{tabular} & $\mathrm{H}$ \\
\hline L. Yuri & 1 & 0 & 0 & 2 & 1 & 2 & 1 & 1 & 2 & 2 & 1 & 2 & 0 & 2 & & 0 & 2 & 1 & 1 & & & 1 & $\begin{array}{l}29 \mathrm{pt} \\
72 \%\end{array}$ & A \\
\hline N. Ivan & 1 & 0 & 1 & 0 & 0 & 2 & 1 & 2 & 1 & 2 & 1 & 2 & 1 & 2 & & 0 & 1 & 2 & 1 & & & 2 & \begin{tabular}{|l|}
$27 \mathrm{pt}$ \\
$64 \%$
\end{tabular} & A \\
\hline N. Lera & 1 & 0 & 0 & 0 & 0 & 1 & 1 & 1 & 1 & 0 & 0 & 0 & 0 & 0 & & 0 & 1 & 0 & 0 & & & 0 & \begin{tabular}{|c|}
$8 \mathrm{pt}$ \\
$20 \%$
\end{tabular} & $\begin{array}{l}\mathrm{L} \\
\mathrm{A}\end{array}$ \\
\hline N. Andrei & 2 & 1 & 1 & 2 & 0 & 2 & 1 & 1 & 2 & 2 & 2 & 2 & 2 & 1 & & 1 & 2 & 1 & 2 & & & 2 & $\begin{array}{l}17 \mathrm{pt} \\
42 \%\end{array}$ & $\begin{array}{l}\mathrm{L} \\
\mathrm{A}\end{array}$ \\
\hline N. Natalia & 2 & 1 & 1 & 2 & 1 & 2 & 1 & 2 & 2 & 1 & 2 & 2 & 1 & 2 & & 0 & 1 & 2 & 2 & & & 1 & \begin{tabular}{|l|}
$32 \mathrm{pt}$ \\
$81 \%$
\end{tabular} & A \\
\hline P. Daria & 2 & 1 & 1 & 2 & 0 & 2 & 1 & 1 & 2 & 2 & 2 & 2 & 2 & 1 & & 1 & 2 & 2 & 2 & & & 2 & $\begin{array}{l}22 \mathrm{pt} \\
56 \%\end{array}$ & $\mathrm{~A}$ \\
\hline S. Danil & 1 & 1 & 0 & 0 & 1 & 1 & 1 & 0 & 0 & 2 & 1 & 2 & 1 & 2 & & 1 & 1 & 2 & 2 & & & 1 & $\begin{array}{c}21 \mathrm{pt} \\
52.2 \\
\%\end{array}$ & $\begin{array}{l}\text { L } \\
\text { A }\end{array}$ \\
\hline T. Sergei & 2 & \begin{tabular}{|lll}
1 & &
\end{tabular} & 1 & 2 & 2 & 2 & 1 & 2 & 2 & 1 & 2 & 1 & 1 & 2 & & 0 & 1 & 2 & 2 & & & 1 & $\begin{array}{l}32 \mathrm{pt} \\
80 \%\end{array}$ & A \\
\hline F. Evelina & 1 & 1 & \begin{tabular}{|l|}
1 \\
\end{tabular} & 0 & 0 & 0 & 0 & 1 & 1 & 1 & 1 & 0 & 0 & 0 & & 0 & 0 & 1 & 0 & & & 0 & \begin{tabular}{l|}
$11 \mathrm{pt}$ \\
$28 \%$
\end{tabular} & $\mathrm{~L}$ \\
\hline
\end{tabular}

The following results were identified in the group: 5 children have an average level of development of feelings of patriotism; 3 children are below average and 2 children are high.

3 Method "My attitude to my small homeland".

The children of the group scored 122 points out of 220 possible. The average percentage is $55 \%$ (Table 6 ). 
The table above shows that 6 children in the group have an average level of development of feelings of patriotism, 2 children have a high level, 6 are medium, 3 children are below average and 0 are low.

For the convenience of comparing the results of the diagnostic methods carried out, two diagrams were drawn up according to the results of the ascertaining stage and the control one.

The children scored 487 points out of a possible 847 , that is, the average percentage of the development of feelings of patriotism in this group is $57 \%$, i.e. average when compared with the assessment criteria. This result represents level 3 according to T.M. Maslova (Figure 2).

Table 6. Results of the control stage of the method "My attitude to my small homeland".

\begin{tabular}{|c|c|c|c|c|c|c|c|c|c|c|c|c|}
\hline \multirow{2}{*}{$\begin{array}{c}\text { Surname, } \\
\text { Name }\end{array}$} & \multicolumn{10}{|c|}{ Question number, results in points } & \multirow{2}{*}{ हैं } & \multirow{2}{*}{ ग } \\
\hline & 1 & 2 & 3 & 4 & 5 & 6 & 7 & 8 & 9 & 10 & & \\
\hline G. Suzanne & 2 & 2 & 2 & 2 & 1 & 2 & 1 & 2 & 1 & 1 & $\begin{array}{l}18 \mathrm{pt} \\
90 \%\end{array}$ & $\mathrm{H}$ \\
\hline L. Nikita & 2 & 1 & 1 & 1 & 2 & 1 & 1 & 1 & 0 & 0 & $\begin{array}{l}10 \mathrm{pt} \\
50 \%\end{array}$ & $\mathrm{~A}$ \\
\hline L. Yuri & 2 & 1 & 2 & 2 & 1 & 2 & 1 & 2 & 1 & 1 & $\begin{array}{l}15 \mathrm{pt} \\
75 \%\end{array}$ & $\mathrm{H}$ \\
\hline N. Ivan & 2 & 1 & 2 & 1 & 1 & 2 & 1 & 1 & 1 & 0 & $\begin{array}{l}12 \mathrm{pt} \\
60 \%\end{array}$ & A \\
\hline N. Lera & 1 & 2 & 1 & 1 & 1 & 1 & 1 & 1 & 1 & 1 & $\begin{array}{l}11 \mathrm{pt} \\
55 \%\end{array}$ & A \\
\hline N. Andrei & 2 & 1 & 2 & 1 & 1 & 1 & 1 & 0 & 1 & 1 & $\begin{array}{l}11 \mathrm{pt} \\
55 \%\end{array}$ & $\mathrm{~A}$ \\
\hline N. Natalia & 2 & 1 & 2 & 1 & 2 & 0 & 1 & 0 & 1 & 1 & $\begin{array}{l}11 \mathrm{pt} \\
55 \%\end{array}$ & A \\
\hline P. Daria & 1 & 1 & 2 & 1 & 0 & 1 & 1 & 1 & 1 & 1 & $\begin{array}{l}10 \mathrm{pt} \\
50 \%\end{array}$ & $\begin{array}{l}\mathrm{L} \\
\mathrm{A}\end{array}$ \\
\hline S. Danil & 2 & 1 & 2 & 1 & 0 & 1 & 1 & 0 & 0 & 1 & $\begin{array}{c}9 \mathrm{pt} \\
45 \%\end{array}$ & $\begin{array}{l}\mathrm{L} \\
\mathrm{A}\end{array}$ \\
\hline T. Sergei & 2 & 1 & 1 & 1 & 2 & 0 & 1 & 1 & 1 & 1 & $\begin{array}{l}11 \mathrm{pt} \\
55 \%\end{array}$ & $\mathrm{~A}$ \\
\hline F. Evelina & 1 & 1 & 2 & 1 & 0 & 1 & 1 & 1 & 1 & 1 & $\begin{array}{l}10 \mathrm{pt} \\
50 \%\end{array}$ & $\begin{array}{l}\mathrm{L} \\
\mathrm{A}\end{array}$ \\
\hline
\end{tabular}

Thus, the training program developed by us for the association "Russia is our home!" on the patriotic education of children of primary school age, using the psychological and pedagogical conditions identified by us by means of folklore is effective, but it is necessary to continue working with children in this direction. 


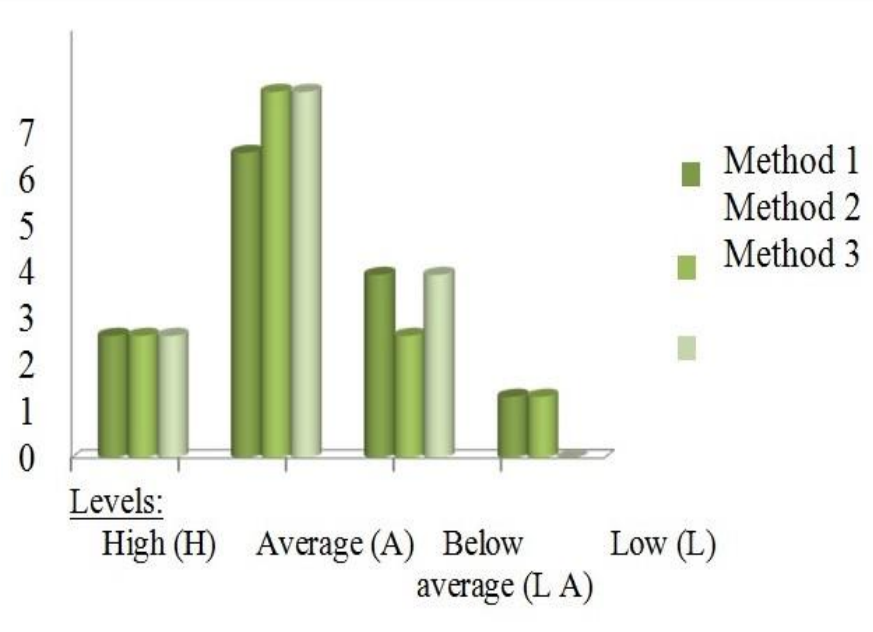

Fig. 2. Comparative diagram of the results of diagnostics of ascertaining and control experiments.

\section{Conclusions}

Thus, the optimal purposeful combination of psychological and pedagogical conditions aimed at the patriotic education of children of primary school age will help us to educate a real citizen of our country. The originality of patriotic education at primary school age is predetermined by the characteristics of this age, as well as by the specificity of the moral development of the personality of the primary school children as a whole. This specificity is predetermined, first of all, by the general features of this age:

- highly strong susceptibility of the primary school children to external influences;

- great excitability of their emotional sphere;

- predisposition to assimilate the new;

- brightness of perception, impulsive behavior, etc.

\section{References}

1. Federal Law "On Education in the Russian Federation" dated December 29, 2012 No. 273-FZ (the last edition) [Electronic resource] http://www.consultant.ru/document/cons_doc_LAW_140174/

2. The concept of spiritual and moral development and education of the personality of a citizen of Russia [Electronic resource] https://mosmetod.ru/metodicheskoeprostranstvo/nachalnaya-shkola/orkse/fgos/kontseptsiya-dukhovno-nravstvennogorazvitiya-i-vospitaniya-lichnosti-grazhdanina-rossii.html

3. Decree of the Government of the Russian Federation of 30.12.2015 No. 1493 (revised from 30.03.2020) "On the state program" Patriotic education of citizens of the Russian Federation for 2016-2020" [Electronic resource] http://www.consultant.ru/document/cons_doc_LAW_192149/

4. L.I. Bozhovich, Personality and its formation in childhood, 200 (1968)

5. L.S. Vygotsky, Child development psychology, 350 (2004)

6. D.I. Feldshtein, Structural-content characteristics of the personality development process, Growing up psychology, 670 (2004) 
7. N.K. Krupskaya, Children is our future (1985)

8. L.V. Kokueva, Spiritual and moral education of preschoolers on the cultural traditions of their people (2005)

9. A.S. Makarenko, Presentation at the pedagogical school (1951)

10. V.A. Sukhomlinsky, Education of Soviet patriotism among schoolchildren: From the experience of a rural school (1959)

11. A.S. Ryleeva, The development of the student's personal qualities in the process of forming a civil-patriotic position, Kostanay, 218-219 (2017)

12. S.V. Emanova, E.A. Kazantseva, Formation of spiritual and moral competencies of students in an institution of additional education in the context of the new federal state educational standards, Spiritual and moral development and education of the personality of a citizen of Russia in the context of new standards, 67-72 (2015) 